\title{
Notas dos Editores
}

Este novo número da revista Latitude expressa os passos avante que o periódico tem dado nos últimos anos, mesmo enfrentando condições adversas. Neste número, inauguramos uma programação de dossiês e de traduções de textos escritos por pesquisadores que alcançaram grande influência em suas especialidades.

Neste número, temos o dossiê "Ser criança no Brasil hoje: (re)invenções da infância em contexto de mudança social", organizado por Marina Saraiva e Flávia Ferreira Pires. Ele inclui a tradução do seminal texto "Por que os antropólogos não gostam de crianças?" de Lawrence A. Hirschfeld - professor do Departamento de Antropologia e Psicologia da New School for Social Research (NSSR), especialmente para os pesquisadores de fenômenos associados à infância.

Reunindo artigos que expressam o interesse em expansão da Antropologia pelos fenômenos relacionados à criança, este dossiê mostra-se um representante desse novo desdobramento de investigações no Brasil. Recomendamos a leitura da apresentação do dossiê, que oferece mais informações sobre o percurso recente dessa linha de estudos da Antropologia, no Brasil e no mundo.

Um sintoma do crescimento da revista é o avanço de sua posição no quadro de avaliações do Qualis-CAPES. Adiantamos uma casa, saindo de B4 para B3, mas não estamos acomodados. Apesar no ano difícil para o país, o final de 2016 foi de boas notícias para a Latitude, tendo o periódico sido contemplado no último edital de apoio a periódicos lançado pela Fundação de Apoio à Pesquisa do Estado de Alagoas. Isso nos permitirá adentrar a era dos digital objects identifiers (DOI's), tornando possível divulgar melhor os artigos em novas bases internacionais de indexação.

Com isso vamos devagar, mas firmes, rumo à consolidação da revista. No próximo número teremos o dossiê "Sociologia e Erotismo", no qual será publicada uma tradução de um importante artigo de um dos herdeiros do sociólogo alemão Norbert Elias, o holandês Cas Wouters. Em seguida, teremos mais três dossiês já agendados.

Buscando conciliar a publicação de artigos cuja qualidade é atestada por pares, e às cegas, com o compromisso de diálogo com questões de interesse da sociedade alagoana, prosseguiremos com a seção de

Latitude, Vol. 10, no 2, pp. 163-164, 2016

DOI: https://doi.org/10.28998/2179-5428.20160201 
Notas dos Editores

entrevistas com intelectuais alagoanos. Assim, divulgamos para as novas gerações o que tem formado o repertório de problemas humanos em Alagoas, oferecendo fundamentos para a formação de mapas intergeracionais do que tem sido posto à vista e do que não tem sido interesse dos grupos intelectuais de Alagoas.

Ademais, ganhamos mais um reforço na equipe editorial, com a chegada de Marina Saraiva. Seja bem-vinda! Mas prepara-te! Muito trabalho a fazer.

Ah, não esqueçamos o habitual: aproveitem esse novo número!

Fernando de Jesus Rodrigues

Marina Saraiva

Paolo Totaro

Editores

Dezembro de 2016 